\title{
THE IMPROVEMENT OF HEAT INSULATION FOR ROOF STEEL PLATES BY TRIZ APPLICATION
}

Ruey-Sen Chiu

Institute of Technology Management, Chung Hua University, Hsinchu, Taiwan., rdesignchiu@yahoo.com.tw

Shao-Tsai Cheng

Department of Construction Management, Chung Hua University, Hsinchu, Taiwan.

Follow this and additional works at: https://jmstt.ntou.edu.tw/journal

Part of the Engineering Commons

\section{Recommended Citation}

Chiu, Ruey-Sen and Cheng, Shao-Tsai (2012) "THE IMPROVEMENT OF HEAT INSULATION FOR ROOF STEEL PLATES BY TRIZ APPLICATION," Journal of Marine Science and Technology. Vol. 20: Iss. 2, Article 2.

DOI: $10.51400 / 2709-6998.1830$

Available at: https://jmstt.ntou.edu.tw/journal/vol20/iss2/2

This Research Article is brought to you for free and open access by Journal of Marine Science and Technology. It has been accepted for inclusion in Journal of Marine Science and Technology by an authorized editor of Journal of Marine Science and Technology. 


\title{
THE IMPROVEMENT OF HEAT INSULATION FOR ROOF STEEL PLATES BY TRIZ APPLICATION
}

\author{
Ruey-Sen Chiu ${ }^{1}$ and Shao-Tsai Cheng ${ }^{2}$
}

Key words: TRIZ, plate paint, heat insulation.

\begin{abstract}
More and more colored plates have been used on roofs in the steel buildings in Taiwan, such as roofs of high-technology factories and offices of large-scale construction sites. Facing the impacts of global economic crisis as well as the exhaustion of natural resources, we should seriously look at the issue of energy saving and try every possible method to save energy in daily life. In architecture industry, architects have devoted themselves to green buildings. However, there should be an inventive way to upgrade heat insulation of external building structures. The studies on this topic in Taiwan mainly focus on the heat insulation of air flow and use the compound-heatproof materials to decrease the heat load of buildings. There were a few researches done on the invention of heat-proof paint on roof plates.

This paper applies TRIZ, the Russian acronym for theory of inventive problem solving, to develop a new heat-proof paint used on the colored roof plates. After conducting and analyzing several heat resistant tests, this study has successfully developed a new paint that upgrades the solar reflectance and heat insulation of the plate paint, which saves over $24 \%$ of electricity and thus achieves the goal of saving energy.
\end{abstract}

\section{INTRODUCTION}

Nowadays, the number of colored steel deck roofs used in steel-plate buildings in Taiwan has been increasing, such as high technology factories and huge construction firms. Architects have been trying to decrease the heat inside buildings and to upgrade heat insulation as well as visor designs of architectures. During summer noon, horizontal solar radiation is over $1000 \mathrm{~W} / \mathrm{m}^{2}$ in Taiwan [1]. The solar radiation leads to high room temperature, causing unnecessary waste of electricity in air conditioning.

Paper submitted 04/16/10; revised 06/18/10; accepted 07/02/10. Author for correspondence: Ruey-Sen Chiu (e-mail: rdesignchiu@yahoo.com.tw).

${ }^{I}$ Institute of Technology Management, Chung Hua University, Hsinchu, Taiwan.

${ }^{2}$ Department of Construction Management, Chung Hua University, Hsinchu, Taiwan.
The number of buildings in steel deck plates has been increasing, so more steel deck plates with sprayed coating have also been used on roofs. However, Taiwan is a small island with earthquakes and tropical weather. The plates on roofs are exposed to the hot-humid weather so the surfaces of plates get rusted and have stains due to acid rain, which causes poor outlooks of buildings. This paper aims at the application of TRIZ, the Russian acronym for theory of inventive problem solving, to develop colored steel plates with new heat-proof paint by conducting several heat resistance tests. The test results prove that this new developed paint advances solar reflectance as well as heat insulation of the plates and achieves the goal of saving energy [1].

\section{METHODOLOGY}

\section{TRIZ Inventive Principles}

TRIZ is a Russian acronym of Teoriya Resheniya Izobreatatelskikh Zadatch, meaning Theory of Inventive Problem Solving. The new inventive principles of TRIZ are professional theory generated by professional analysts from studying over 200 thousands of updated research results and patents of different fields. This experience has significant reference values in instructing invention of new products in various industries. On the base of analyzing all patents around the world, Altshuller has proposed 39 engineering parameters (EPs), which is a breakthrough to traditional technologies, and he has further categorized them into 40 inventive principles (IPs) [2, 7]. To improve invention systems and solve problems through TRIZ, first of all, is to use 2 of 39 EPs to represent two internal potentially conflicting requirements and then to search for the inventive principles that solve problems from the contradiction matrix. After 50 years of development, TRIZ has become one of problem-solving methodologies for technology and invention. This method has successfully overcome difficulties in developing new products throughout U.S.S.R., U.S.A., Europe, Japan ․etc. Dr. Savransky, an internationally well-known TRIZ expert, has given a TRIZ definition-TRIZ is the methodology based on common knowledge, human-orientation and problem-solving system [9].

\section{Inventive Problem Solving Procedures in TRIZ}

To solve inventive problems through TRIZ is first to identify and specify problems, then to convert problems to similar 
Table 1. The contradiction matrix chart (partially extracted) [5].

\begin{tabular}{|c|c|c|c|c|c|c|}
\hline $\begin{array}{l}\begin{array}{r}\text { Deteriorated } \\
\text { parameters } \\
\text { be improved }\end{array} \\
\text { parameters to }\end{array}$ & $\begin{array}{l}\text { 01. weight of moving } \\
\text { object }\end{array}$ & $\begin{array}{l}\text { 02. weight of stationary } \\
\text { object }\end{array}$ & $\cdots$ & 18. brightness & $\cdots$ & 39. productivity \\
\hline 01. weight of moving object & & - & $\cdots$ & $\begin{array}{c}19,01 \\
32 \\
\end{array}$ & $\ldots$ & $\begin{array}{l}35,03 \\
24,37 \\
\end{array}$ \\
\hline 02. weight of stationary object & - & & $\cdots$ & $\begin{array}{c}19,32 \\
35 \\
\end{array}$ & $\cdots$ & $\begin{array}{l}01,28 \\
15,35 \\
\end{array}$ \\
\hline$\vdots$ & $\vdots$ & $\vdots$ & & $\vdots$ & & $\vdots$ \\
\hline 17. temperature & $\begin{array}{l}36,22 \\
06,38 \\
\end{array}$ & $\begin{array}{c}22,35 \\
32 \\
\end{array}$ & $\cdots$ & $\begin{array}{l}32,30 \\
21,16 \\
\end{array}$ & $\cdots$ & $\begin{array}{c}15,28 \\
35\end{array}$ \\
\hline$\vdots$ & $\vdots$ & $\vdots$ & & $\vdots$ & & $\vdots$ \\
\hline 35. adoptibility & $\begin{array}{l}01,06 \\
15,08 \\
\end{array}$ & $\begin{array}{l}19,15 \\
29,16 \\
\end{array}$ & $\ldots$ & $\begin{array}{l}06,22 \\
26,01 \\
\end{array}$ & $\cdots$ & $\begin{array}{l}35,28 \\
06,37\end{array}$ \\
\hline$\vdots$ & $\vdots$ & $\vdots$ & & $\vdots$ & & $\vdots$ \\
\hline 39. productivity & $\begin{array}{l}35,26 \\
24,37\end{array}$ & $\begin{array}{l}28,27 \\
15,03\end{array}$ & $\ldots$ & $\begin{array}{l}26,17 \\
19,01\end{array}$ & $\cdots$ & \\
\hline
\end{tabular}

Note: The numbers in Table 1 stand for the category numbers listed in the 40 inventive principles.

40 inventive principles

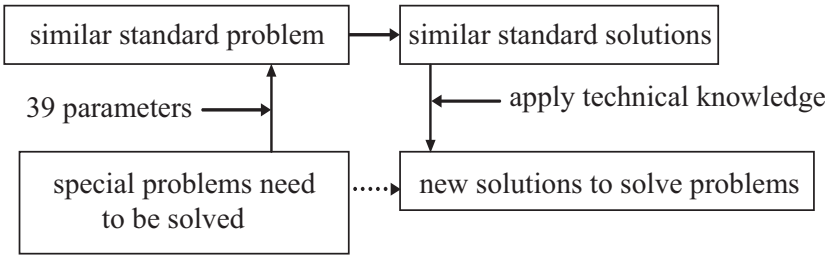

Fig. 1. Inventive problem-solving procedures in TRIZ [9].

standard ones according to the methodology provided by TRIZ. Thus, a standard solution is formed by summing up and categorizing similar standard problems, finally, applying this standard solution to solve problems. The whole process is shown as Fig. 1 [9].

\section{TRIZ-The Contradiction Matrix Chart}

When designers face a problem in invention and try to improve a feature of products, most of time, the situation turns out that another feature gets worse. The traditional way is to compromise but TRIZ uses elimination instead. According to Altshuller's analysis, there are totally 39 EPs in technical contradictions and Altshuller has organized these patterns of problem-solving in matrix, which is the most well-known contradiction matrix in TRIZ. The horizontal axis in matrix refers to the negative effects that occur when attempting to get positive effects, while the lateral is the positive effects planned to be improved. Assuming when designers intend to improve feature A but cause to deteriorate feature B, designers can get solutions from inventive principles and TRIZ contradiction matrix efficiently. The contradiction matrix consists of 39 rows and columns, totally 1521 elements [5]. Table 1 is the chart of contradiction matrix. Fig. 2 is the flow chart of problem solving in TRIZ.

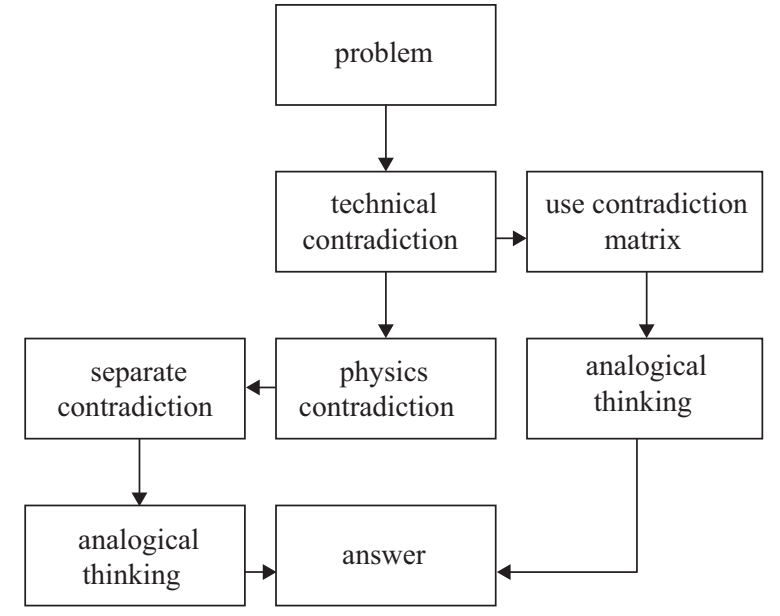

Note: Then counter point of the horizontal axis (deteriorating parameters) and lateral axis (parameters needed to be improved) is the principle suggested to solve problems.

Fig. 2. The flow chart of contradiction solving in TRIZ [5].

\section{TRIZ Application to Development of Heat-Proof Paint on Steel Plates}

When designers face an inventive problem in developing new heat-proof paint and try to improve a product or a feature, the situation turns out that another product or feature gets worse. The traditional way is to compromise but TRIZ uses elimination instead. The idealization $=$ useful function/harmful function. The purpose is to maximize the useful function while minimizing the harmful result [5].

This paper is to improve solar reflectance of heat-proof paint, such as to upgrade the reflectance of physical property by applying TRIZ contradiction matrix and 40 principles [1].

The brief elaboration is as below. Traditionally to improve reflectance of materials is to thicken heat-proof materials with 
Table 2 . The contradiction Matrix chart.

\begin{tabular}{|c|c|c|c|}
\hline Parameters to be improved & 13. stability of objects & 18. brightness & 35. adaptability \\
\hline 17. temperature & $1,35,32$ & $32,30,21,16$ & $2,18,27$ \\
\hline 30. harmful factors acting on objects & $35,24,30,18$ & $1,19,32,13$ & $35,11,22,31$ \\
\hline 35. adaptability & $35,30,14$ & $6,22,26,1$ & \\
\hline
\end{tabular}

Note: The top four IPs most frequently used are IP35, IP1, IP32 and IP30.

(IP35) Transformation of the physical and chemical states of an object.

(IP1) Segmentation.

(IP32) Changing the color.

(IP30) Flexible membranes or thin film.

two or three compound materials. However, in this study, we follow the traditional way to thicken the new paint on the backside of roof plates, but it causes small air bubbles between layers of paint, which makes the paint peeling off and leads to poor outlooks of plates and, worse, a construction failure.

Moreover, thickening heat-resistant materials causes more weights on roof structure and thus plate structures need to be strengthened, which increases construction cost and unnecessary capital burden. Through applying the contradiction matrix procedure, a solution is suggested that is to convert the physical property of materials to chemical property, which is to add suitable amount of thixotropy resin in the mixture of material Polypropylene resin (A-type) [4]. While mixing these materials, the air within the mixture dries the material, forming mini bubbles in the mixture. After this compound material dries, it gets lighter and has better heat insulation. This new method improves the physical property of the paint and also advances the stability of the material. To upgrade the physical property of heat-proof paint, this study applies TRIZ contradiction matrix and 40 inventive principles to conduct this revision. The parameters which need to be improved and the deteriorated ones are listed as following: temperature (EP17), harmful elements on objects (EP30), adaptability (EP35), stability of objects (EP13) and brightness (EP18), the five parameters in the contradiction matrix. To solve these five contradictions, four inventive principles are singled out in TRIZ as shown in Table 2.

\section{Introduction of Heat-Proof Paint on Plate}

As the study of Hideki Takebayashi \& Masakazu Moriyama indicates [3], the Table 2 in the study mentions solar reflectance (Albedo) of highly reflective white paint is 0.74 , which is better than that of other colors. Thus, white color is selected as heat-proof paint for roof plates in this study. This study uses 2 kinds of heat-proof paint materials on roofing steel plates. The material A, Polypropylene resin, is mainly used in adhesives, water-proof materials, protective materials, concrete addictives and so on. Material B is mixture of two different heat-insulation materials which are SxOy-Al type and SixOy-Al type couplier agent, mainly used in water-proof materials, fire-proof materials, concrete additives, retarders and so on [11]. The mixture of these two materials in suitable proportion is a heat-proof material for roof steel plates. This mixture gets solid after it dries due to the two reasons stated below. 1. This mixture in resin breaks surface tension, which allows water to vaporize and speeds up hardening without causing cracks. 2. The mixture has vacant spaces itself which stop thermal conductivity, thermal current and solar radiation [1].

Only two materials are used in this new developed heatresistant paint. Polypropylene resin, material A, is easier to control in production cost and manufacturing process. Furthermore, this type of resin is more stable, which secures the stability of the resin, ensuring the reliability of analysis results. Polypropylene resin, material A, is the common name for Butyl Acrylate, Methyl Methacrylate and Methacrylic acid. It is weak acid. Besides, the mixture of two heat-insulation materials (material B) is the mixture of SxOy-Al type and SixOy-Al type couplier agent, aluminosilicate salty, silice, and titanium dioxide. It is alkalescent. The goal of this new developed product is to fit and satisfy customers' needs in green buildings. Through the design of Taguchi Quality Engineering, the best combinations of manufacture parameters are formed, thus providing high-quality production conditions. Before a new product is developed, customers' demands and expectations need to be settled and converted to a requirement in every aspect of production so as to achieve the goal of satisfying customers [1].

\section{The Definition of Thermal Conductivity Rate $\left(U_{i}\right.$ Rate) and MRT}

(1) Thermal conductivity rate also known as $U_{i}$ rate refers to the thermal conductivity rate of exterior buildings when the temperature difference between indoors and outdoors is $1 \mathrm{~K}$. The formula is $U_{i}\left[\mathrm{~W} /\left(\mathrm{m}^{2} \cdot \mathrm{K}\right)\right]$.

(2) MRT, Mean Radiant Temperature, refers to the average radiation temperature of walls. The formula is shown as follows.

$$
\operatorname{MRT}=\frac{\Sigma\left(A_{i} \times t_{i}\right)}{\Sigma A_{i}}
$$


$A_{i}$ refers to the size of walls and $t_{i}$ is the radiation temperature of walls.

MRT $=t_{g}+0.237 v^{0.5}\left(t_{g}-t\right) v:$ wind speed $(\mathrm{m} / \mathrm{s}) ; t_{g}:$ temperature taken by globe thermometers; $t$ : the indoors temperature.

\section{The Calculation of Average Radiation Heat Inside the} Boxes and Temperature Taken by Globe Thermometers

(1) Indoors heat radiation is usually indicated as average radiation temperature $\left(T_{\mathrm{mrt}}\right)$ [10]. The average radiation refers to the average rate of surface temperature that influences exchange of radiation heat in people.

(2) It is difficult to have a precise calculation of average indoors radiation temperature. The formula commonly used in engineering is $T_{\mathrm{mrt}}=\left(T_{1} A_{1}+T_{2} A_{2}+\ldots+T_{n} A_{n}\right) /\left(A_{1}+\right.$ $\left.A_{2}+\ldots+A_{n}\right)$. This formula indicates $T_{\text {mrt }}$ is average indoors radiation temperature $(\mathrm{K}), T_{1}, T_{2}, \ldots$, and $T_{n}$ are indoors surface temperatures and $A_{1}, A_{2}, \ldots$, and $A_{n}$ are measurements of the indoors surface $\left(\mathrm{m}^{2}\right)$.

(3) The average radiation temperature can be also acquired from the temperature taken by globe thermometers which are the black globe thermometers in this experiment $\left(T_{g}\right)$. Belding's formula can be used to transfer the temperature of average radiation to that of black globe thermometers. The formula is $T_{\mathrm{mrt}}=T_{g}+2.4 v^{0.5}\left(T_{g}-T_{a}\right)$.

(4) The interior test box is a closed space so the indoors wind speed $v$ is nearly equal to zero. In the preceding paragraph of formula $T_{\text {mrt }}$ is nearly equal to $T_{g}$.

(5) $T_{\text {mrt }}$ and MRT refer to the same definition. They both mean average radiation temperature.

\section{EXPERIMENT FACILITIES}

\section{Experiment Designs of the 3 Boxes in the Test}

The design of boxes in this experiment is based on Fig. 2 (The components of a test cell) in the study [8]. This study simulates the mould and builds up the boxes for heat resistance tests. They are conducted on 3 various paints with different paint thickness. The designs of the test boxes, facilities used and assembling process are stated in Table 3.

1.1 The location of facilities in test boxes: to have two stages of heat resistance tests on plate paint, several facilities are installed in each test box as Fig. 3 shows.

\subsection{The plate paint of each box in each group:}

There are 2 stages in heat resistance tests that aim to compare and prove the heat insulation of the new paint. In each stage, there are 3 groups in this heat resistance test, one control group, Plate B and two experiment groups, Plate A \& C, which is as Table 4 shows.

\section{First stage of heat resistance comparison test on the 3 boxes}

The experiment was conducted during 10 a.m. to 2 p.m.
Table 3. The installation of facilities in test boxes.
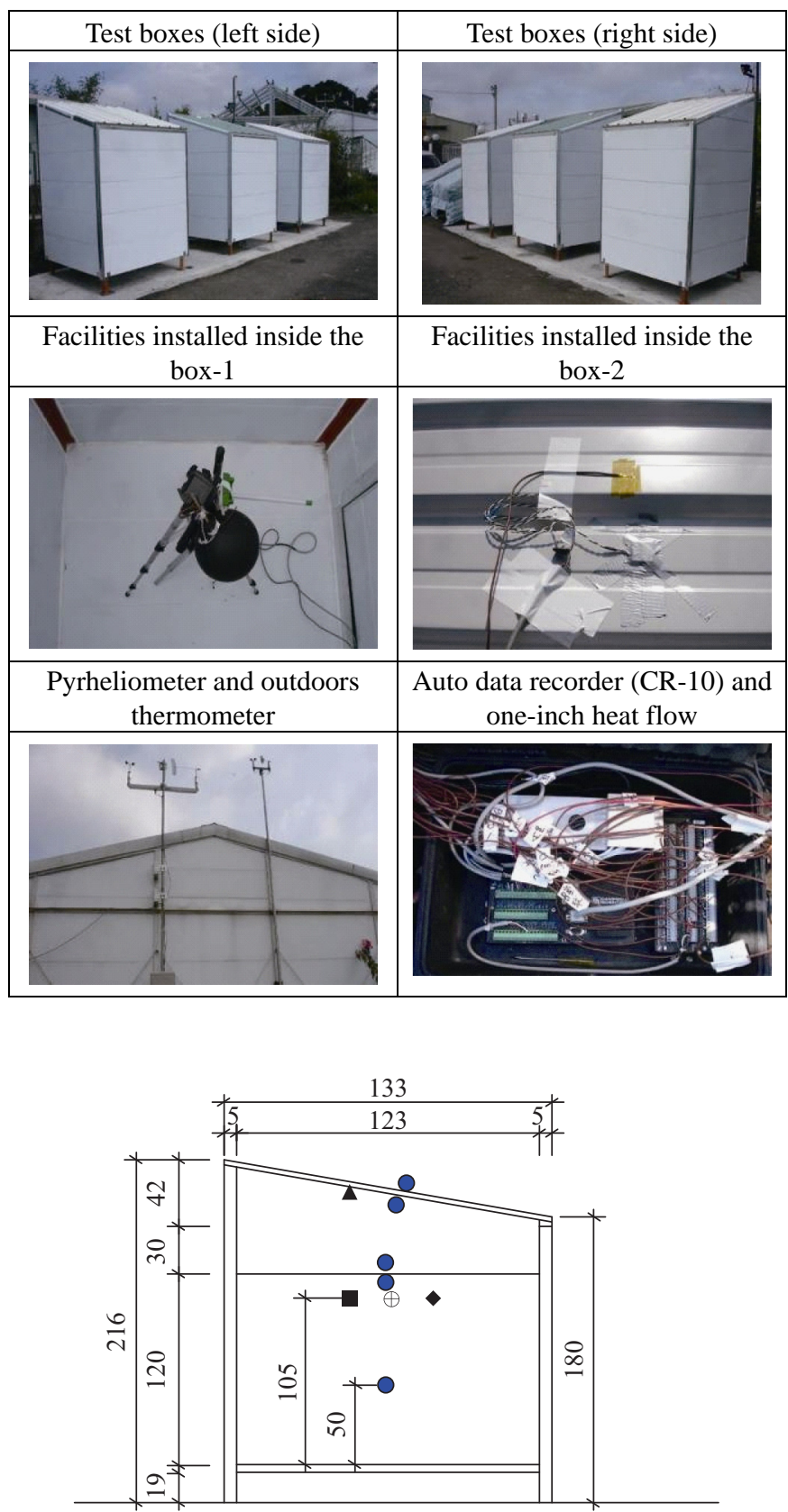
Symbols:
○: T-type Thermocouple
$\Delta$ : Heat flow meters
a : Hydrometers
$\bullet:$ Anemometers
$\oplus$ : Tg. (black globe thermometers)

Fig. 3. The location of facilities in test box.

from Feb. $8^{\text {th }}$ to $23^{\text {rd }}$ in 2010. The size and measurement of paint for each plate in the 3 boxes are indicated from Tables 5 7. 
Table 4. The introduction of each group in heat resistance test.

\begin{tabular}{|l|c|c|c|}
\hline \multicolumn{1}{|c|}{ Group } & Experiment group-plate A & Control group-plate B & Experiment group-plate C \\
\hline A: white SixOy-Al type paint & & \\
B: plate with original colored paint & \\
C: white SxOy-Al type paint & &
\end{tabular}

Table 5. The introduction of plate paint and tests in $1^{\text {st }}$ stage.

\begin{tabular}{|c|c|c|c|c|}
\hline Test Date & Group & Experiment group-plate A & Control group-plate B & Experiment group-plate $\mathrm{C}$ \\
\hline $2010 / 2 / 8$ & paint & 3 layers of SixOy-Al type & light green plate & 3 layers of SxOy-Al type paint \\
\hline $1^{\text {st }}$ test & Thickness of paint & $\begin{array}{l}0.65 \mathrm{~mm} \text { (including the loss during } \\
\text { spraying) }\end{array}$ & Overlooked & $\begin{array}{l}0.65 \mathrm{~mm} \text { (including the loss during } \\
\text { spraying) }\end{array}$ \\
\hline $2010 / 2 / 10$ & paint & 4 layers of SixOy-Al type & light green plate & 4 layers of SxOy-Al type paint \\
\hline $2^{\text {nd }}$ test & Thickness of paint & $\begin{array}{l}0.8 \mathrm{~mm} \text { (including the loss during } \\
\text { spraying) }\end{array}$ & Overlooked & $\begin{array}{l}0.8 \mathrm{~mm} \text { (including the loss during } \\
\text { spraying) }\end{array}$ \\
\hline $2010 / 2 / 23$ & paint & 5 layers of SixOy-Al type & light green plate & 5 layers of SxOy-Al type paint \\
\hline $3^{\text {rd }}$ test & Thickness of paint & $\begin{array}{l}0.95 \mathrm{~mm} \text { (including the loss during } \\
\text { spraying) }\end{array}$ & Overlooked & $\begin{array}{l}0.95 \mathrm{~mm} \text { (including the loss during } \\
\text { spraying) }\end{array}$ \\
\hline
\end{tabular}

Table 6. Outdoors weather condition.

\begin{tabular}{|c|c|c|c|c|}
\hline Date & $\begin{array}{c}\text { Wind } \\
\text { speed }\end{array}$ & Humidity & $\begin{array}{c}\text { Solar } \\
\text { radiation }\end{array}$ & $\begin{array}{c}\text { Outdoors } \\
\text { temperature }\end{array}$ \\
\hline $2010-02-08$ & $1.24 \mathrm{~m} / \mathrm{s}$. & $67 \%$ & $657.25 \mathrm{~W} / \mathrm{m}^{2}$ & $23.82^{\circ} \mathrm{C}$ \\
\hline $2010-02-10$ & $1.17 \mathrm{~m} / \mathrm{s}$. & $57 \%$ & $676.57 \mathrm{~W} / \mathrm{m}^{2}$ & $26.31^{\circ} \mathrm{C}$ \\
\hline $2010-02-23$ & $1.40 \mathrm{~m} / \mathrm{s}$. & $62 \%$ & $746.48 \mathrm{~W} / \mathrm{m}^{2}$ & $22.27^{\circ} \mathrm{C}$ \\
\hline
\end{tabular}

Table 7. The heat resistance test results of 3 boxes.

\begin{tabular}{|c|c|c|c|}
\hline Date & $\begin{array}{c}\text { temperature } \\
\text { difference be- } \\
\text { tween front/back } \\
\text { side of plate A }\end{array}$ & $\begin{array}{c}\text { temperature } \\
\text { difference be- } \\
\text { tween front/back } \\
\text { side of plate B }\end{array}$ & $\begin{array}{c}\text { temperature } \\
\text { difference be- } \\
\text { tween front/back } \\
\text { side of plate } \mathrm{C}\end{array}$ \\
\hline $2010-02-08$ & $4.10^{\circ} \mathrm{C}$ & $1.41^{\circ} \mathrm{C}$ & $3.77^{\circ} \mathrm{C}$ \\
\hline $2010-02-10$ & $3.51^{\circ} \mathrm{C}$ & $1.46^{\circ} \mathrm{C}$ & $3.89^{\circ} \mathrm{C}$ \\
\hline $2010-02-23$ & $4.14^{\circ} \mathrm{C}$ & $0.71^{\circ} \mathrm{C}$ & $3.68^{\circ} \mathrm{C}$ \\
\hline
\end{tabular}

2.1 There are 3 tests in the first stage of heat resistance comparison test on plate paint. Taking the weather conditions (as Table 6 shown) into consideration, the test results of 3 tests are shown in Fig. 4 and Fig. 9.

2.2 The test results of heat resistance: Comparison tests of 3 experiments in $1^{\text {st }}$ stage are analyzed shown as Tables 7 9 show.

2.3 In the 3 tests of $1^{\text {st }}$ stage, the analysis of the heat resistance comparison tests indicates Box A in 1st group has the better performance in the test. The temperature difference between front/back side of plate in Box $\mathrm{A}$ is $4.14^{\circ} \mathrm{C}$, temperature taken by globe thermometer in the box is $27.84^{\circ} \mathrm{C}$ and its estimated

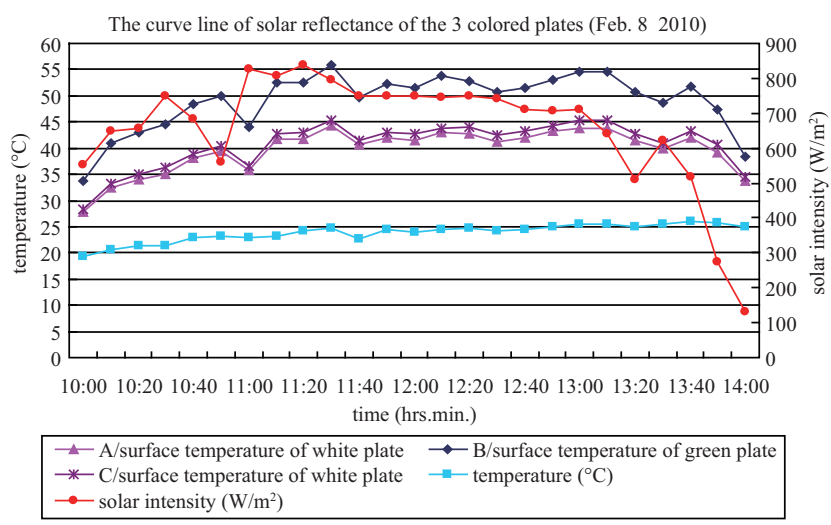

Fig. 4. The curve line of solar reflectance of the 3 colored plates.

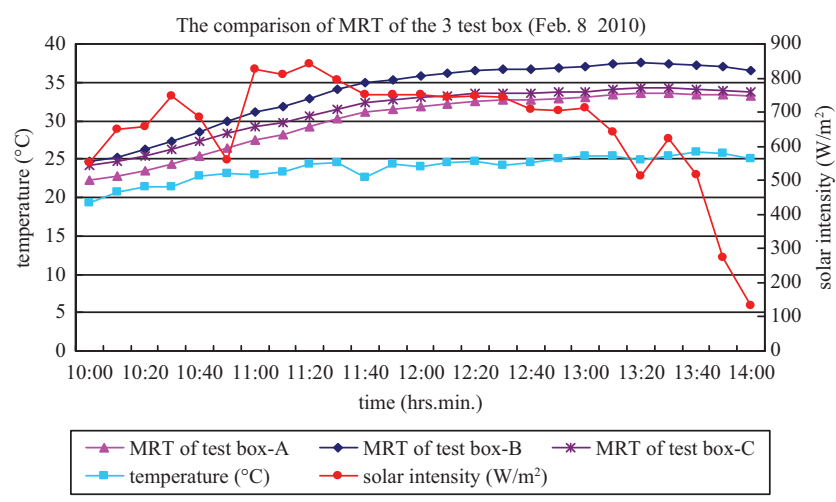

Fig. 5. The comparison of MRT of the 3 test boxes.

$U_{i}$ rate is 3.68 , which are all better than the parameters in Boxes B and C. Therefore, in these 3 tests with totally 9 boxes, Box A with white SixOy-Al type paint has the best perform- 
Table 8. The test results of temperature taken by globe thermometers in 3 boxes.

\begin{tabular}{|c|c|c|c|}
\hline Date & $\begin{array}{c}\text { Temperature } \\
\text { taken by globe } \\
\text { thermometer in } \\
\text { Box A }\end{array}$ & $\begin{array}{c}\text { Temperature } \\
\text { taken by globe } \\
\text { thermometer in } \\
\text { Box B }\end{array}$ & $\begin{array}{c}\text { Temperature } \\
\text { taken by globe } \\
\text { thermometer in } \\
\text { Box C }\end{array}$ \\
\hline $2010-02-08$ & $30.01^{\circ} \mathrm{C}$ & $33.63^{\circ} \mathrm{C}$ & $31.23^{\circ} \mathrm{C}$ \\
\hline $2010-02-10$ & $32.07^{\circ} \mathrm{C}$ & $36.07^{\circ} \mathrm{C}$ & $33.38^{\circ} \mathrm{C}$ \\
\hline $2010-02-23$ & $27.84^{\circ} \mathrm{C}$ & $31.80^{\circ} \mathrm{C}$ & $29.20^{\circ} \mathrm{C}$ \\
\hline
\end{tabular}

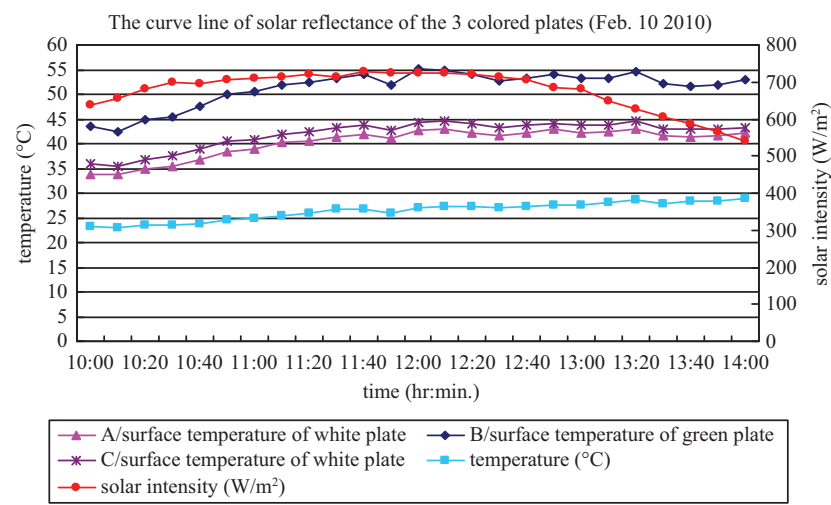

Fig. 6. The curve line of solar reflectance of the 3 colored plates.

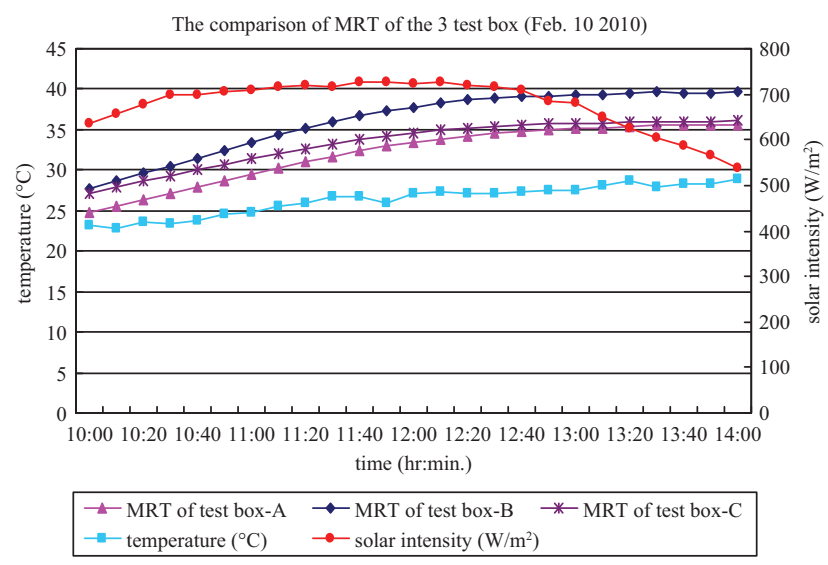

Fig. 7. The comparison of MRT of the 3 test boxes.

ance in the test and the plate with 5 layers of white SixOy-Al type paint is the second ranked.

3. Summary: The test results of $1^{\text {st }}$ stage prove that Box A with white SixOy-Al type paint has the best performance in the test and the plate with 5 layers of white SixOy-Al type paint is the second ranked. In the $2^{\text {nd }}$ stage of the heat resistance test, we conduct another test to reconfirm the finding we get in the first stage. The experiment was conducted from 10 a.m to 2 p.m on Feb. $24^{\text {th }}$ to $28^{\text {th }}$ of 2010 . The paint, size and measurement of each plate in the 3 boxes of $2^{\text {nd }}$ stage are introduced in Table 10 as following:
Table 9. The estimated $U_{i}$ rate in the 3 boxes.

\begin{tabular}{|c|c|c|c|}
\hline Date & $\begin{array}{c}\text { A-the estimated } \\
U_{i} \text { rate }\end{array}$ & $\begin{array}{c}\text { B-the estimated } \\
U_{i} \text { rate }\end{array}$ & $\begin{array}{c}\text { C-the estimated } \\
U_{i} \text { rate }\end{array}$ \\
\hline $2010-02-08$ & 3.50 & 5.90 & 3.72 \\
\hline $2010-02-10$ & 3.66 & 5.89 & 3.52 \\
\hline $2010-02-23$ & 3.68 & 5.59 & 3.92 \\
\hline
\end{tabular}

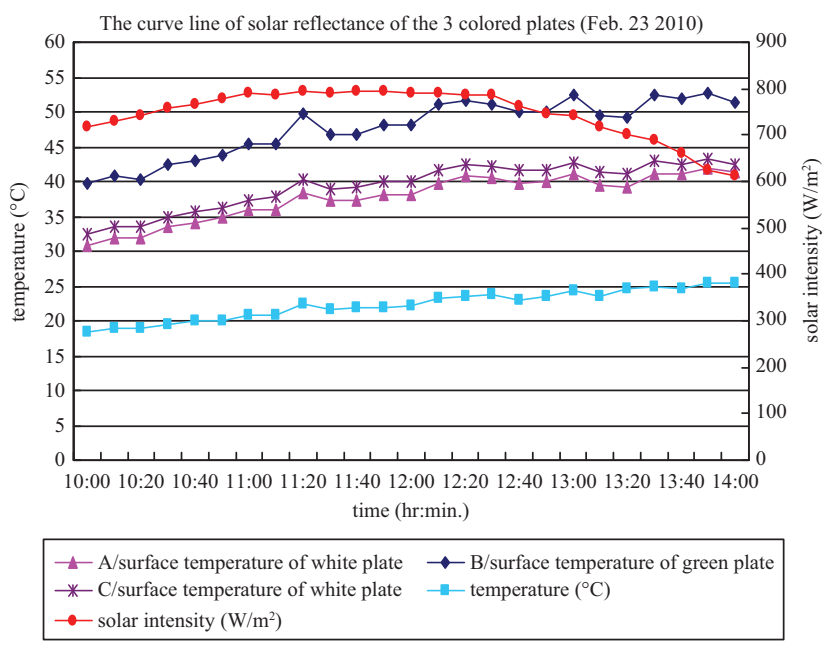

Fig. 8. The curve line of solar reflectance of the 3 colored plates.

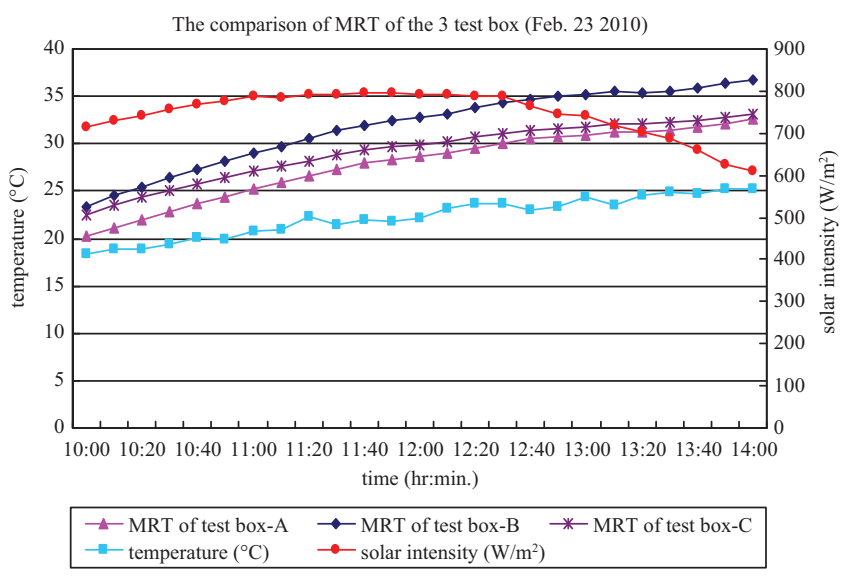

Fig. 9. The comparison of MRT of the 3 test boxes.

3.1 There are 3 tests in the first stage of heat resistance test on plate paint (the weather conditions in Table 11 are taken into consideration.) The test results of 3 boxes in $2^{\text {nd }}$ stage are shown as Fig. 10 and Fig. 11 show.

3.2 The test results of 3 boxes in $2^{\text {nd }}$ stage prove 3 important heat resistance standards. The test results are analyzed in Table 12.

3.3 In the test of $2^{\text {nd }}$ stage (totally 3 boxes), the analysis of the heat resistance tests proves that Box A in $1^{\text {st }}$ group has the best 
Table 10. Introduction of plate paint and size of the 3 tests in $2^{\text {nd }}$ stage.

\begin{tabular}{|c|c|c|c|c|}
\hline Dest & Group & Experiment group-plate A & Control group- plate B & Experiment group- plate C \\
\hline $2010 / 2 / 24$ & paint & 5 layers of SixOy-Al type paint & Light green plate & 5 layers of SxOy-Al type paint \\
\hline Test 1 & Thickness of paint & $\begin{array}{c}0.95 \mathrm{~mm} \\
\text { (including the loss during spraying) }\end{array}$ & Overlooked & $\begin{array}{c}0.95 \mathrm{~mm} \\
\text { (including the loss during spraying) }\end{array}$ \\
\hline
\end{tabular}

Table 11. Outdoors weather condition.

\begin{tabular}{|c|c|c|c|c|}
\hline Date & Wind speed & Humidity & Solar radiation & Outdoors temperature \\
\hline $2010-02-24$ & $1.26 \mathrm{~m} / \mathrm{s}$. & $45 \%$ & $751.97 \mathrm{~W} / \mathrm{m}^{2}$ & $24.99^{\circ} \mathrm{C}$ \\
\hline
\end{tabular}

Table 12. The test results of 3 boxes in $2^{\text {nd }}$ stage.

\begin{tabular}{|c|c|c|c|}
\hline \multirow{5}{*}{ Date } & Box A & Box B & Box C \\
\hline \multirow{5}{*}{$2010 / 2 / 24$} & $\begin{array}{l}\text { Temperature difference between } \\
\text { front/back side of plate A }\end{array}$ & $\begin{array}{l}\text { Temperature difference between } \\
\text { front/back side of plate B }\end{array}$ & $\begin{array}{l}\text { Temperature difference between } \\
\text { front/back side of plate } \mathrm{C}\end{array}$ \\
\cline { 2 - 4 } & $4.13^{\circ} \mathrm{C}$ & $0.44^{\circ} \mathrm{C}$ & $3.76^{\circ} \mathrm{C}$ \\
\cline { 2 - 4 } & $\begin{array}{l}\text { Temperature taken by globe } \\
\text { thermometer in Box A }\end{array}$ & $\begin{array}{l}\text { Temperature taken by globe } \\
\text { thermometer in Box B }\end{array}$ & $\begin{array}{l}\text { Temperature taken by globe } \\
\text { thermometer in Box } \mathrm{C}\end{array}$ \\
\cline { 2 - 4 } & $32.31^{\circ} \mathrm{C}$ & $37.03^{\circ} \mathrm{C}$ & $33.63^{\circ} \mathrm{C}$ \\
\cline { 2 - 4 } & Estimated $U_{i}$ rate of Box A & Estimated $U_{i}$ rate of Box B & Estimated $U_{i}$ rate of Box C \\
\cline { 2 - 4 } & 3.65 & 5.50 & 3.86 \\
\hline
\end{tabular}

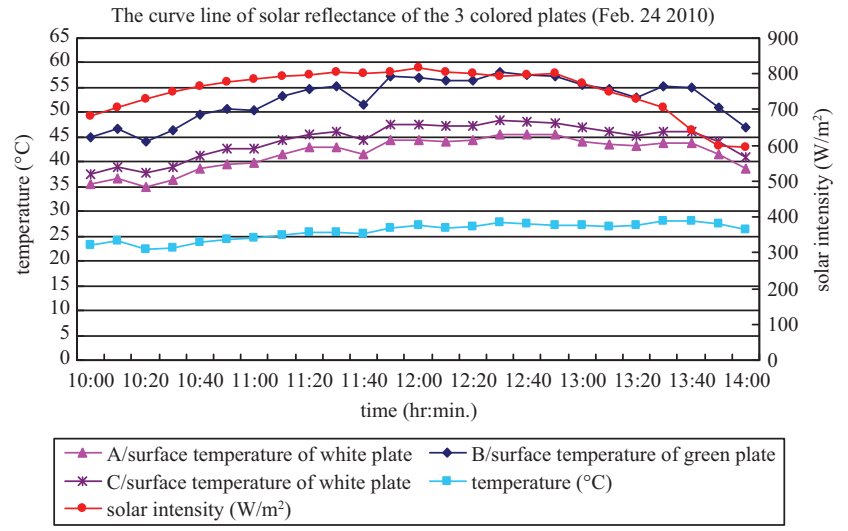

Fig. 10 The curve line of solar reflectance of the 3 colored plates.

performance in the test. The temperature difference between front/back side of plate of Box A is $4.13^{\circ} \mathrm{C}$, temperature taken by globe thermometer of the box is $32.31^{\circ} \mathrm{C}$ and its estimated $U_{i}$ rate is 3.65, which are all better than Boxes B and $\mathrm{C}$. Therefore, in this test, Box A with white SixOy-Al type paint and the plates with 5 layers of white SixOy-Al type paint have the best performance in the test.

\section{SUMMARY AND DISCUSSION}

(1) From the $U_{i}$ rate calculated based on the test results of the two stages (totally 12 groups), it proves that the heat re-

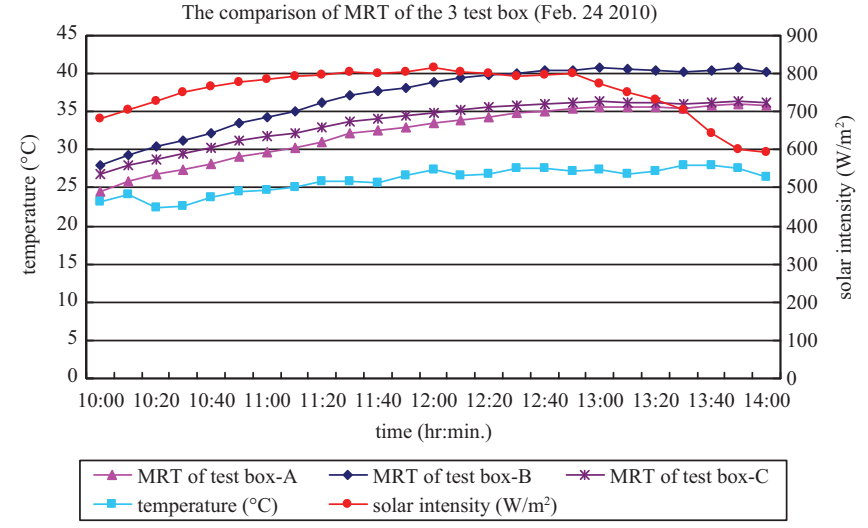

Fig. 11. The comparison of MRT of the 3 test boxes.

sistance of Box A and Box $\mathrm{C}$ in each group are better than Box B. The change of $U_{i}$ rate in Boxes $\mathrm{A}$ and $\mathrm{C}$ in each group is small and the temperature difference between surface temperature of the paint and that below the plate is about $1.95^{\circ} \mathrm{C} \sim 4.14^{\circ} \mathrm{C}$, which demonstrates the heat insulation of the paint.

(2) The test results of each group show the surface temperature of plate paint, temperature taken by globe thermometers in boxes and the heat resistance of plate paint. The readings in these two stages are listed in Tables 13 15.

(3) The average thermal conductivity, $U_{i}$ rate, is acquired as 
Table 13. The comparison of surface temperature in the 3 groups of the heat resistance test.

\begin{tabular}{|c|c|c|c|c|}
\hline Date & $\begin{array}{c}\text { Plate-A } \\
\text { (experiment group) }\end{array}$ & $\begin{array}{c}\text { Plate-B } \\
\text { (control group) }\end{array}$ & $\begin{array}{c}\text { Plate-C } \\
\text { (experiment group) }\end{array}$ & $\begin{array}{c}\text { Temperature difference of the highest } \\
\text { and lowest temperature }{ }^{\circ} \mathrm{C}\end{array}$ \\
\hline $2010-02-08$ & 39.60 & 49.09 & 40.70 & 9.49 \\
\hline $2010-02-10$ & 40.22 & 51.27 & 41.94 & 11.05 \\
\hline $2010-02-23$ & 37.75 & 47.73 & 39.40 & 9.98 \\
\hline $2010-02-24$ & 41.73 & 52.77 & 44.35 & 11.04 \\
\hline Average temperature ${ }^{\circ} \mathrm{C}$ & 39.83 & 50.22 & 41.60 & 10.39 \\
\hline Ranking & 1 & 3 & 2 & \\
\hline
\end{tabular}

Table 14. The heat resistance test results of the 3 groups.

\begin{tabular}{|c|c|c|c|c|c|}
\hline group & plate color & $\begin{array}{l}\text { Heat resistance of } \\
\text { plate paint }\left({ }^{\circ} \mathrm{C}\right)\end{array}$ & $\begin{array}{l}\text { Solar Radiation heat } \\
\text { taken by globe } \\
\text { thermometers }\left({ }^{\circ} \mathrm{C}\right)\end{array}$ & Ranking & $\begin{array}{l}\text { Estimated saving of electricity fee } \\
\text { (save } 6 \% \text { each decrease of } 1^{\circ} \mathrm{C} \text { ) }\end{array}$ \\
\hline $1-\mathrm{A}$ & $\begin{array}{l}\text { Light green plate with } 3 \text { layers of } \\
\text { white SixOy-Al type paint }\end{array}$ & 4.10 & 30.01 & 1 & \multirow{3}{*}{$21.72 \%$} \\
\hline $1-\mathrm{B}$ & Light green plate without spraying & 1.41 & 33.63 & 3 & \\
\hline $1-\mathrm{C}$ & $\begin{array}{l}\text { Light green plate with } 3 \text { layers of } \\
\text { white SxOy-Al type paint }\end{array}$ & 3.77 & 31.23 & 2 & \\
\hline $2-\mathrm{A}$ & $\begin{array}{l}\text { Light green plate with } 4 \text { layers of } \\
\text { white SixOy-Al type paint }\end{array}$ & 3.51 & 32.07 & 1 & \multirow{3}{*}{$24.00 \%$} \\
\hline $2-\mathrm{B}$ & Light green plate without spraying & 1.46 & 36.07 & 3 & \\
\hline $2-\mathrm{C}$ & $\begin{array}{l}\text { Light green plate with } 4 \text { layers of } \\
\text { white SxOy-Al type paint }\end{array}$ & 3.89 & 33.38 & 2 & \\
\hline $3-\mathrm{A}$ & $\begin{array}{l}\text { Light green plate with } 5 \text { layers of } \\
\text { white SixOy-Al type paint }\end{array}$ & 4.14 & 27.84 & 1 & \multirow{3}{*}{$23.76 \%$} \\
\hline $3-\mathrm{B}$ & Light green plate without spraying & 0.71 & 31.80 & 3 & \\
\hline $3-\mathrm{C}$ & $\begin{array}{l}\text { Light green plate with } 5 \text { layers of } \\
\text { white SxOy-Al type paint }\end{array}$ & 3.68 & 29.20 & 2 & \\
\hline $4-\mathrm{A}$ & $\begin{array}{l}\text { Light green plate with } 5 \text { layers of } \\
\text { white SixOy-Al type }\end{array}$ & 4.13 & 32.31 & 1 & \multirow{3}{*}{$28.32 \%$} \\
\hline 4-B & Light green plate without spraying & 0.44 & 37.03 & 3 & \\
\hline $4-\mathrm{C}$ & $\begin{array}{l}\text { Light green plate with } 5 \text { layers of } \\
\text { white SxOy-Al type }\end{array}$ & 3.76 & 33.63 & 2 & \\
\hline \multicolumn{3}{|c|}{$\begin{array}{l}\text { The heat resistance test result of plate paint; } \\
\text { estimated saving of electricity fee }\end{array}$} & \multicolumn{2}{|c|}{ Total average rate } & $24.45 \%$ \\
\hline
\end{tabular}

Note: (1) The average indoors radiation temperature and temperature taken by globe thermometers are convertible via the Belding's formula by which it estimates the saving of electricity fee. (2) As the announcement of Taiwan Economics department indicates, every $1{ }^{\circ} \mathrm{C}$ drop in room temperature saves $6 \%$ electricity fee.

Table 15 shows. The formula of $U_{i}$ rate for heat resistance in each group is according to the R.O.C. regulation of energy-saving for buildings [6]. The formula of thermal conductivity $U_{i}$ can be shown as follows:

$$
U_{i}=\frac{1}{1 / h_{o}+\Sigma d_{x} / k_{x}+r_{a}+1 / h_{i}}
$$

Comparison and analysis of average $U_{i}$ rate in each group are shown in Table 15. $U_{i}$ rate of the light green plate with white SixOy-Al type paint is 3.62 , has the best heat insulation performance.

\section{CONCLUSION}

(1) The two stages of heat resistance tests were conducted from 10 a.m. to 2 p.m. During this period of time, the solar radiation is over $600 \mathrm{~W} / \mathrm{m}^{2}$ which is taken as the base of calculation in this heat resistance test. From the test results, the estimated $U_{i}$ rate taken is the max. rate on that day, which is more accurate and close to the actual condition.

(2) From the test results of these two stages, we notice that the mixture of two different heat-insulation materials is better than the paint on plate B. Among all the plates, the light green plate with 5 layers of white SixOy-Al type paint has 
Table 15. The comparison of $U_{i}$ rate in 3 groups.

\begin{tabular}{|c|c|c|c|c|c|}
\hline Plate no. & Plate color & $\begin{array}{l}\text { Plate thickness } \\
(\mathrm{mm})\end{array}$ & $\begin{array}{l}\text { Paint thickness } \\
(\mathrm{mm})\end{array}$ & $\begin{array}{l}\text { Average thermal conductivity } \\
\left(U_{i} \text { rage }\right)\end{array}$ & Ranking \\
\hline $1-1$ & $\begin{array}{l}\text { Light green plate with } 3 \text { layers of } \\
\text { white SixOy-Al type paint }\end{array}$ & 0.45 & 0.65 & 3.50 & 1 \\
\hline $1-2$ & Light green plate & 0.45 & overlooked & 5.90 & 3 \\
\hline $1-3$ & $\begin{array}{l}\text { Light green plate with } 3 \text { layers of } \\
\text { white SxOy-Al type paint }\end{array}$ & 0.45 & 0.65 & 3.72 & 2 \\
\hline $2-1$ & $\begin{array}{l}\text { Light green plate with } 4 \text { layers of } \\
\text { white SixOy-Al type paint }\end{array}$ & 0.45 & 0.8 & 3.66 & 2 \\
\hline $2-2$ & Light green plate & 0.45 & overlooked & 5.89 & 3 \\
\hline $2-3$ & $\begin{array}{l}\text { Light green plate with } 4 \text { layers of } \\
\text { white SxOy-Al type paint }\end{array}$ & 0.45 & 0.8 & 3.52 & 1 \\
\hline $3-1$ & $\begin{array}{l}\text { Light green plate with } 5 \text { layers of } \\
\text { white SixOy-Al type paint-1 }\end{array}$ & 0.45 & 0.95 & 3.68 & 1 \\
\hline $3-2$ & Light green plate-1 & 0.45 & overlooked & 5.59 & 3 \\
\hline $3-3$ & $\begin{array}{l}\text { Light green plate with } 5 \text { layers of } \\
\text { white SxOy-Al type paint-1 }\end{array}$ & 0.45 & 0.95 & 3.92 & 2 \\
\hline $4-1$ & $\begin{array}{l}\text { Light green plate with } 5 \text { layers of } \\
\text { white SixOy-Al type paint-2 }\end{array}$ & 0.45 & 0.95 & 3.65 & 1 \\
\hline $4-2$ & Light green plate-2 & 0.45 & overlooked & 5.50 & 3 \\
\hline $4-3$ & $\begin{array}{l}\text { Light green plate with } 5 \text { layers of } \\
\text { white SxOy-Al type paint-2 }\end{array}$ & 0.45 & 0.95 & 3.86 & 2 \\
\hline \multicolumn{2}{|c|}{ Light green plate with white SixOy-Al type paint } & \multicolumn{2}{|c|}{ Average } & 3.62 & 1 \\
\hline & Light green plate & \multicolumn{2}{|c|}{ Average } & 5.72 & 3 \\
\hline \multicolumn{2}{|c|}{ Light green plate with white $\mathrm{SxOy}-\mathrm{Al}$ type paint } & \multicolumn{2}{|c|}{ Average } & 3.76 & 2 \\
\hline
\end{tabular}

the best performance in solar reflectance and heat insulation, which also has the greatest improvement in heat resistance of plate paint.

(3) The box sprayed with several layers of heat-proof paint has the best performance in heat resistance test. The globe thermometers in each box show that the heat resistance of Boxes $\mathrm{A}$ and $\mathrm{C}$ is better than box B. Based on the calculation that every $1{ }^{\circ} \mathrm{C}$ drop in room temperature saves $6 \%$ of electricity fee, it indicates the improved range is around $22 \% \sim 28 \%$ with the total average rate of $24.45 \%$. This proves that the new developed heat-proof paint in this study has the function of saving energy and this construction method proposed in this paper is effective.

(4) In the future studies about heat-proof paint on roof plates, we suggest the best heat resistance comparison test should be conducted with plates of same materials, thickness, paint layers and thickness of paint. More than two groups are needed in the test so that the temperature readings are more accurate. Moreover, it is recommended to compare the range of high temperature period in curve lines. Therefore, the tests will be performed in a more solid approach, which makes heat resistance test results and the performance of heat-proof paint closer to the actual condition.

\section{NOMENCLATURE}

the heat insulation of part $i$ in air space $\left(\mathrm{m}^{2 \circ} \mathrm{C} / \mathrm{W}\right)$, if no air space, then $r_{a}=0$

$h_{o} \quad$ the thermal conductivity of surface (standard rate is 23.0$)\left(\mathrm{W} / \mathrm{m}^{2 \circ} \mathrm{C}\right.$ ) (Taiwan adopts $3 \mathrm{~m} / \mathrm{s}$ and the practical thermal conductivity is $\alpha o$ )

$h_{i} \quad$ the thermal conductivity of internal surface (standard rate 7.0$)\left(\mathrm{W} / \mathrm{m}^{2 \circ} \mathrm{C}\right)$ (Taiwan adopts horizon with downward heat flow. The practical thermal conductibility is $\alpha i$ )

$k_{x} \quad$ the thermal conductivity of layer $x$ inside part $i\left(\mathrm{~W} / \mathrm{m}^{2 \circ} \mathrm{C}\right)$

$d_{x} \quad$ the thickness of layer $x$ material inside part $i$ $(\mathrm{m})$

$R_{x}=\Sigma d_{x} / k_{x} \quad$ the heat insulation of layer $x$ material $\left(\mathrm{m}^{2 \circ} \mathrm{C} /\right.$ $T_{\mathrm{mrt}} \quad$ W)

$T_{g} \quad$ the temperature taken by globe thermometer in boxes $\left[{ }^{\circ} \mathrm{C}\right]$

$T_{a} \quad$ indoors air temperature

$v \quad$ indoors wind speed $(\mathrm{m} / \mathrm{sec}$.)

\section{REFERENCES}

1. Chiu, R. S. and Cheng, S. T., "The application of innovative technology for improvement of heat insulation performance on the steel deck roofs," The CRIOCM2009 International Symposium on Advancement of Construction Management and Real Estate, Nanjing, China, Vol. 6, pp. $2657-$ 2664 (2009).

2. Domb, E. and Tate, K., "40 inventive principles with examples," from http://www.triz-journal.com/. (1997). 
3. Hideki, T. and Masakazu, M., "Surface heat budget on green roof and high reflection roof for mitigation of urban heat island," Building and Environment, Vol. 42, pp. 2971-2979 (2007).

4. Hung, C. Z., translated, Analysis of Paint Materials, Fu Han Publisher, Tainan, Taiwan (2000).

5. Hung, Y. C., The Introduction and Application of TRIZ, Optimal Design Laboratory of Yuan Ze University, Taoyuan, Taiwan (2004).

6. Lin, S. D., The Regulation and Case Studying of Energy Saving in Architecture Book 6: Housing Buildings, The Project in the Regulation and Calculation of Green Architectures, Construction Journal, Taipei (2005).

7. Liu, C. C., A Study of TRIZ Method Improvements and Eco-Innovative
Design Methods, Doctor Dissertation, Graduate Institute of Mechanical Engineering, National Cheng Kung University, Tainan, Taiwan (2003).

8. Soubdhan, T., Feuillard, T., and Bade, F., "Experimental evaluation of insulation material in roofing system under tropical climate," Solar Energy, Vol. 79, pp. 311-320 (2005).

9. Tan, J. H., Inventive Design-TRIZ, The Theory of Inventive Problem Solving, China Mechanical Industry Publisher, Hebei, China (2006).

10. Yeh, Y., Solar Eenergy Environment of Architecture, Shu Shing Publisher, p. 10 (1997).

11. Yu, Z. M., The Book of Chemistry Products in China, 1st and 2nd volume, China Material Publisher, China (1988). 